\title{
A Review of Isothermal Amplification Methods and Food-Origin Inhibitors against Detecting Food-Borne Pathogens
}

\author{
Ye-Ji Moon, So-Young Lee and Se-Wook Oh *
}

check for updates

Citation: Moon, Y.-J.; Lee, S.-Y.; Oh, S.-W. A Review of Isothermal Amplification Methods and Food-Origin Inhibitors against Detecting Food-Borne Pathogens. Foods 2022, 11, 322. https:/ /doi.org/ 10.3390 /foods 11030322

Academic Editor: Dario De Medici

Received: 14 December 2021

Accepted: 18 January 2022

Published: 24 January 2022

Publisher's Note: MDPI stays neutral with regard to jurisdictional claims in published maps and institutional affiliations.

Copyright: (C) 2022 by the authors. Licensee MDPI, Basel, Switzerland. This article is an open access article distributed under the terms and conditions of the Creative Commons Attribution (CC BY) license (https:// creativecommons.org/licenses/by/ $4.0 /)$.
Department of Food and Nutrition, Kookmin University, Seoul 136-702, Korea; yjm0316@kookmin.ac.kr (Y.-J.M.) leesoyoung0423@kookmin.ac.kr (S.-Y.L.)

* Correspondence: swoh@kookmin.ac.kr

\begin{abstract}
The isothermal amplification method, a molecular-based diagnostic technology, such as loop-mediated isothermal amplification (LAMP) and recombinase polymerase amplification (RPA), is widely used as an alternative to the time-consuming and labor-intensive culture-based detection method. However, food matrices or other compounds can inhibit molecular-based diagnostic technologies, causing reduced detection efficiencies, and false-negative results. These inhibitors originating from food are polysaccharides and polyphenolic compounds in berries, seafood, and vegetables. Additionally, magnesium ions needed for amplification reactions can also inhibit molecular-based diagnostics. The successful removal of inhibitors originating from food and molecular amplification reaction is therefore proposed to enhance the efficiency of molecular-based diagnostics and allow accurate detection of food-borne pathogens. Among molecular-based diagnostics, PCR inhibitors have been reported. Nevertheless, reports on the mechanism and removal of isothermal amplification method inhibitors are insufficient. Therefore, this review describes inhibitors originating from food and some compounds inhibiting the detection of food-borne pathogens during isothermal amplification.
\end{abstract}

Keywords: molecular amplification; detection method; food metrix; bacteria; inhibition

\section{Introduction}

Food-borne pathogens, such as Salmonella spp., Escherichia coli O157:H7, and Listeria monocytogenes, threaten public health, causing different food-borne diseases and deaths [1] Since small amounts of bacteria are found in food, detection methods capable of detecting even small bacterial quantities are needed [2]. The culture-based detection method, a gold standard for pathogen detection, is time-consuming and labor-intensive [3]. Therefore, polymerase chain reaction (PCR), which was developed as a rapid detection technology based on nucleic-acid bond alignment, greatly reduces detection time, and improves the sensitivity and specificity to increase the detection efficiency of food-borne pathogens $[4,5]$. PCR amplifies nucleic acids through denaturation, annealing, and expansion steps during different temperature cycles, but different temperature cycles can interfere with the nucleic acid amplification process [6-8].

An isothermal amplification method was developed to be conducted at a single temperature, which was subsequently improved by replacing the PCR thermocycling step with Bacillus stearothermophylus (Bst) DNA polymerase, phi DNA polymerase, helicase, and RNase H enzymes with strand displacement activity $[9,10]$. The loop-mediated isothermal amplification (LAMP), recombinase polymerase amplification (RPA), helicase-dependent amplification (HDA), nucleic acid sequence-based amplification (NASBA), rolling circle amplification (RCA), and multiple strand displacement amplification (MDA) are examples of isothermal amplification methods [11-16]. Since the isothermal amplification method 
does not require a thermal cycler, it has high detection efficiency and enables rapid detection [17]. Additionally, the applicability of point-of-care testing (POCT) is also high, and it is effectively applied for detecting food-borne pathogens [12,17].

Although molecular-based diagnostics are the most efficient and effective methods for detecting food-borne pathogens, the detection efficiency is proposed to be decreased because of different inhibitors that produce false-negative results [18,19]. These inhibitors originate from various foods and environmental or clinical samples used in the analysis, and from some compounds used during the amplification reaction and extraction process, in addition to reaction conditions $[19,20]$. Also, fluorescent dye or DNA-binding dye used for amplicon detection after amplification can serve as inhibitors during the process of isothermal amplification [21,22].

PCR inhibitors from foods have been studied and reported upon [19,21,22]. In addition, the isothermal amplification inhibitors have continuously been reported upon. However, it is not enough to report on the inhibitory mechanism and removal strategy compared to PCR. Therefore, isothermal amplification techniques used in food-borne pathogen detection and different inhibitors that interfere with isothermal amplification are described.

\section{Isothermal Amplification Methods}

LAMP is conducted in the presence of Bst DNA polymerase, deoxyribonucleotide triphosphate (dNTP), and 4-6 specific primers (inner and outer primers) that recognize 6-8 specific regions [23]. The Bst DNA polymerase removes the need for high thermocycling because of its activity at $50-70{ }^{\circ} \mathrm{C}$, and the DNA polymerase is less sensitive to food-origin inhibitors $[24,25]$. The use of two outer primers (forward outer primer; F3, and backward outer primer; B3), two inner primers (forward inner primer; FIP, and backward inner primer; BIP), with additional loop primers (forward loop primer; LF, and backward loop primer; LB) also allows sequence-specific detection, improves specificity, and accelerates assay specificity to amplification targets [26]. However, although many long primers increase the reaction yield, a risk of primer dimerization owing to nonspecific interactions simultaneously exists $[9,27]$. To prevent primer dimerization, adding dimethyl sulfoxide (DMSO) and betaine is used as a strategy to decrease nonspecific interactions, thereby giving stability to oligonucleotides [28]. The use of additional compounds can amplify nucleic acids without non-specific amplification, and exponential nucleic acid amplification is achieved while forming loops within 40-60 min at a constant temperature of $60-65{ }^{\circ} \mathrm{C}$ [29]. Then, the amplified product can be detected using turbidity measurement, gel electrophoresis, colorimetry, electrochemiluminescence, lateral flow assay (LFA), and real-time monitoring [30,31].

RPA is conducted while a recombinase protein UvsX from T4-like bacteriophages forms a complex with primers in the presence of ATP and a crowding agent, such as polyethylene glycol (PEG) [32]. The crowding agent prevents spontaneous recombinaseprimer degradation, thereby allowing amplification to begin. It also enhances the amplification efficiency by improving catalytic activity of the enzyme [33,34]. Therefore, using long primers (up to 45 nucleotides) can form secondary structures and potential primer artifacts; recommended length of RPA primers is $30-35$ bases [32,35]. RPA is conducted at relatively low and constant temperatures of $37-42{ }^{\circ} \mathrm{C}$ for $20-40 \mathrm{~min}$, and detection of amplicons are performed through gel electrophoresis, flocculation assay detection, LFA, electrochemical assay, chemiluminescent assay, and silicon microring resonator (SMR)-based photonic assay, and real-time monitoring $[12,34,36]$.

HDA reacts with helicase, two primers, and two accessory proteins; methyl-directed mismatch repair (MutL), and single-stranded DNA (ssDNA) binding (SSB) proteins that stimulate UvrD helicase activity above ten-fold [37,38]. During the HDA replication process, the helicase unwinds double-stranded DNA (dsDNA) for the denaturation. In this step, the accessory proteins are required to bind and stabilize the ssDNA for the prevention of recombination of the complementary strand, thereby allowing primer hybridization [10]. The HDA reaction is divided into two systems: the mesophilic form of HDA (mHDA) and 
the thermophilic form of HDA (tHDA). The mHDA reacts at a medium temperature of $37^{\circ} \mathrm{C}$ using UvrD helicase/Exo-Klenow polymerase; the tHDA reacts at a higher temperature $\left(60-65^{\circ} \mathrm{C}\right)$ using a thermostable Tte-UvrD helicase/Bst DNA polymerase [39]. Compared to $\mathrm{mHDA}, \mathrm{tHDA}$ has a higher sensitivity and efficiency, and simplifies the reaction because it does not need MutL and SSB proteins to stabilize the DNA sequence [11]. The magnesium ion, which serves as a cofactor for the helicase and polymerase, is also used in HDA to increase the enzyme activity, thereby making the enzymes compatible with structurally modified primers $[9,40]$. Subsequently, amplification products are detected using gel electrophoresis, colorimetry assay, LFA, and real-time monitoring [11].

NASBA targets 16s rRNA genes or mRNA transcripts for bacterial detection, enabling the analysis of bacterial viability $[16,41]$. NASBA amplifies single-stranded RNA using two primers and three enzymes (avian myeloblastosis virus reverse transcriptase (AMVRT), RNase H, and T7 DNA-dependent RNA polymerase (DdRp)) [42]. While AVMRT generates complementary complementary DNA by extending primers, dsDNA is formed through RNase H. However, T7 DdRP recognizes the exposed T7 promoter of the dsDNA and initiates transcription to initiate the reaction [42]. Since NASBA enzymes are heat labile, amplifications can be performed at a relatively low temperature, with optimal conditions of $41^{\circ} \mathrm{C}$ for $1.5-2 \mathrm{~h}$ [43]. The low reaction temperature of NASBA, however, can produce to result in false-positive results because of nonspecific primer interactions. Nevertheless, adding DMSO and betaine can prevent this limitation $[44,45]$. Subsequently, amplification products are detected using gel electrophoresis, enzyme-linked immunosorbent assay (ELISA), enzyme-linked gel assay, electrochemiluminescent (ECL), and real-time monitoring with molecular beacons $[9,46]$. When the clustered regularly interspaced short palindromic repeats (CRISPR)/Cas system and NASBA are combined, RNA can be detected with high sensitivity through the NASBACC (NASBA-CRISPR Cleavage) system [47].

RCA has high specificity and sensitivity targeting RNA and DNA [48]. The RCA reaction is conducted using DNA/RNA polymerase (phi29 DNA polymerase or T7 RNA polymerase), short DNA or RNA linear single-stranded primer, circle template, and ligase [49]. DNA/RNA polymerase produces a long single-stranded RCA product (RCAP) complementary to a circular template. Unique oligonucleotide padlock probes (PLP) and T4 DNA ligase or special ssDNA ligase synthesize bacterial single- or double-stranded RNA/DNA templates into single-stranded circular DNA [9]. The various modified RCA systems have been developed for efficient amplification: a linear-RCA (LRCA) or an exponential-RCA (ERCA), such as multiply-primed RCA (MPRCA), hyperbranched RCA (HRCA), and primer-generation RCA (PG-RCA) [42]. The saltatory RCA (SRCA), a simplified form of RCA, has been developed, requiring ligase and PLP for cyclization [14,50]. RCA generally reacts for $1-1.5 \mathrm{~h}$ at $30-65{ }^{\circ} \mathrm{C}$ depending on the reaction system, and amplification products are detected using gel electrophoresis, colorimetry, and real-time monitoring [42].

MDA randomly and massively amplifies single-cell genomic DNA and is compatible with whole genome amplification (WGA) [51,52]. MDA is conducted using modified random hexamer primers, phi29 DNA polymerases (strand-displacing DNA polymerase from bacteriophage Ø29), denatured template DNA, and dNTPs [53]. The modified random hexamer primers eliminate the need to design target-specific primers are designed to anneal to random areas on each strand of the target DNA, thereby forming hyperbranched intermediates and dsDNA amplicons after exponential amplification [54]. The phi29 DNA polymerase enables amplification at a relatively low temperature (typically $30^{\circ} \mathrm{C}$ ) because of its high strand displacement activity; it has a higher replication fidelity and lower error rate than Taq DNA polymerases and Bst DNA polymerases [13,55]. Furthermore, the addition of PEG to the reaction for high-efficiency MDA causes molecular crowding, which enables sensitive allele detection in multiplex short tandem repeat genotyping [56].

Schematic diagram and summary of isothermal amplification techniques are shown in Figure 1 and Table 1. 


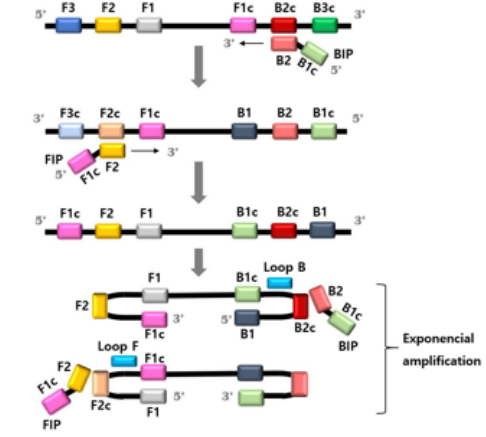

Loop-mediated isothermal amplification (LAMP)

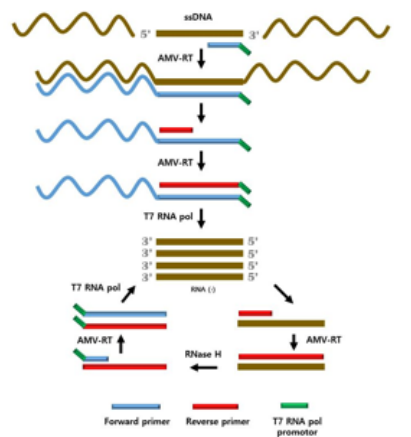

Nucleic acid sequence-based amplification (NASBA)
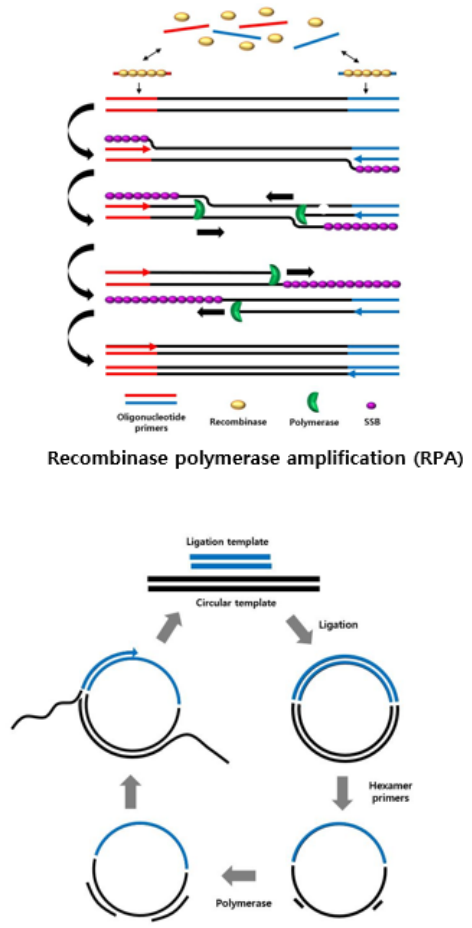

Rolling circle amplification (RCA)

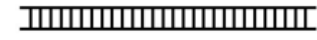

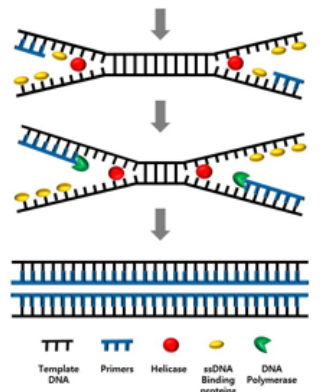

Helicase-dependent amplification (HDA)

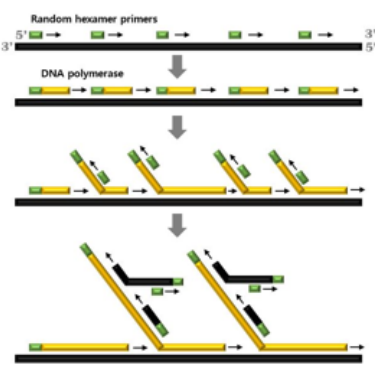

Multiple strand displacement amplification (MDA)

Figure 1. Schematic diagram of isothermal amplification techniques.

Table 1. Summary of comparison among various isothermal amplification methods.

\begin{tabular}{|c|c|c|c|c|c|c|c|c|c|}
\hline $\begin{array}{c}\text { Isothermal } \\
\text { Amplification } \\
\text { Methods }\end{array}$ & $\begin{array}{l}\text { Number } \\
\text { of Primers }\end{array}$ & $\begin{array}{l}\text { Number of } \\
\text { Enzymes }\end{array}$ & Pre-Heating & $\begin{array}{c}\text { Working } \\
\text { Temperature } \\
\left({ }^{\circ} \mathrm{C}\right)\end{array}$ & $\begin{array}{c}\text { Reaction } \\
\text { Time (min) }\end{array}$ & $\begin{array}{c}\text { Target } \\
\text { Template }\end{array}$ & Amplicon & $\begin{array}{l}\text { Resistance } \\
\text { to Inhibitor }\end{array}$ & Reference \\
\hline LAMP & $4-6$ & 1 & No & $60-65$ & $40-60$ & DNA & DNA & High & [29] \\
\hline RPA & 2 & 2 & No & $37-42$ & $20-40$ & DNA & DNA & Low & [12] \\
\hline HDA & 2 & $\begin{array}{c}1 \text { (mHDA), } \\
\text { (tHDA) }\end{array}$ & No & $\begin{array}{c}37 \text { (mHDA), } \\
60-65 \\
\text { (tHDA) }\end{array}$ & $100-120$ & DNA & DNA & High & [11] \\
\hline NASBA & 2 & $2-3$ & Yes & 41 & $90-120$ & RNA & RNA, DNA & Low & [43] \\
\hline RCA & 1 & 1 & Yes & $30-65$ & $60-90$ & $\begin{array}{l}\text { Circular } \\
\text { DNA }\end{array}$ & DNA & Low & [42] \\
\hline MDA & $\begin{array}{l}\text { Random } \\
\text { hexamer } \\
\text { primers }\end{array}$ & 1 & No & 35 & 270 & $\begin{array}{c}\text { Circular or } \\
\text { linear DNAs }\end{array}$ & $\begin{array}{c}\text { Ramified } \\
\text { double- } \\
\text { stranded } \\
\text { DNAs }\end{array}$ & High & [57] \\
\hline
\end{tabular}

Abbreviations used in the table: LAMP, loop-mediated isothermal amplification; RPA, recombinase polymerase amplification; HDA, helicase-dependent amplification; mHDA, mesophilic form of HDA; tHDA, thermophilic form of HDA; NASBA, nucleic acid sequence-based amplification; RCA, rolling circle amplification; MDA, multiple strand displacement amplification.

\section{Inhibitors That Originate from Food during the Isothermal Amplification Process}

Isothermal amplification methods, with a high detection efficiency, sensitivity, and specificity using geometrically amplifying DNA/RNA, have been widely used to detect food-borne pathogens (Table 2) [58]. However, complex food matrices can inhibit the detection of these food-borne pathogens. Therfore, food-origin inhibitors possess inhibitors that make the DNA/RNA extraction challenging, denature DNA or polymerases, or bind magnesium ions to interfere with amplification $[22,24,25]$. Furthermore, it has been reported that these inhibitors are complex polysaccharides, phenolic compounds, and calcium ions $[19,26]$.

Polysaccharides in vegetables, fruits, and seafood can inhibit nucleic acid amplification [19]. Cationic polysaccharides can therefore interfere with DNA amplification initiation to inhibit DNA polymerase activity, thereby inducing competitive binding at the 
primer's binding site owing to their binding properties to anionic particles, such as the template DNA of bacteria [27]. Interference is due to the electrostatic interaction of the anionic phosphate and carboxyl groups in the lipopolysaccharide (LPS) of the extracellular membrane with the cationic molecule, particularly in gram-negative bacterial cells [27,59]. Similar to this inhibition mechanism, chitosan, contained in crab and shrimp, inhibited LAMP by aggregating negatively charged template DNA molecules [27]. A study also reported that polysaccharides in rice interfered with LAMP by inhibiting activity of Bst DNA polymerase [60]. Additionally, polysaccharides can inhibit nucleic acid amplification by forming high-viscous DNA solutions through mechanical spatial entanglements with DNA [61]. This inhibition works because DNA can be denatured by viscous formation processes. High-viscous DNA solutions can inhibit subsequent DNA quantification and amplification [62]. In a previous study, the column/membrane of the DNA extraction kit was blocked because of the highly viscous DNA solution formed by soybean polysaccharides, thereby leading to low DNA yield [63]. Recently, commercial DNA extraction kits have increased the DNA extraction yield by suppressing the formation of viscous DNA $[64,65]$. However, since this method controls the high-viscosity of a DNA solution formed after the inhibition mechanism of polysaccharides, it is impossible to fundamentally remove the inhibition before forming the high-viscosity DNA solution that interferes with amplification. Therefore, future research should alleviate the inhibitory mechanism of polysaccharides in food in advance.

Table 2. Isothermal amplification processes used for detecting food-borne pathogens in foods.

\begin{tabular}{|c|c|c|c|c|}
\hline \multirow{2}{*}{ Type of Food } & \multirow{2}{*}{ Target Bacterial } & \multicolumn{2}{|c|}{ Isothermal Amplification Method } & \multirow{2}{*}{ Reference } \\
\hline & & Nucleic Acid Amplification & Detection Method & \\
\hline \multirow{18}{*}{ Meat } & \multirow{7}{*}{ Salmonella spp. } & \multirow{3}{*}{ LAMP } & Intercalating dye & {$[5,66-68]$} \\
\hline & & & Real-time & {$[69,70]$} \\
\hline & & & LFA & {$[24,71]$} \\
\hline & & RPA & Real-time & [72-74] \\
\hline & & HDA & LFA & [37] \\
\hline & & \multirow{2}{*}{ NASBA } & ECL & [75] \\
\hline & & & Real-time & {$[16]$} \\
\hline & \multirow{3}{*}{ Escherichia coli O157:H7 } & \multirow{2}{*}{ LAMP } & Real-time & {$[76]$} \\
\hline & & & LFA & {$[77]$} \\
\hline & & RPA & DNA-binding dye & {$[78]$} \\
\hline & \multirow{5}{*}{ Listeria monocytogenes } & LAMP & Intercalating dye & [79] \\
\hline & & RPA & LFA & [29,80-82] \\
\hline & & \multirow[b]{2}{*}{ NASBA } & ELISA & [83] \\
\hline & & & Real-time & [84] \\
\hline & & MDA & LFA & {$[54]$} \\
\hline & Vibrio parahaemolyticus & LAMP & LFA & {$[85]$} \\
\hline & \multirow{2}{*}{ Staphylococcus aureus } & LAMP & Intercalating dye & {$[67]$} \\
\hline & & HDA & Fluorescence & {$[86]$} \\
\hline \multirow{11}{*}{ Seafood } & \multirow{2}{*}{ Salmonella spp. } & RPA & LFA & {$[87,88]$} \\
\hline & & NASBA & ECL & {$[75]$} \\
\hline & Escherichia coli O157:H7 & RPA & LFA & [29] \\
\hline & \multirow{4}{*}{ Listeria monocytogenes } & \multirow{3}{*}{ RPA } & Real-time & [89] \\
\hline & & & LFA & {$[29,80,82]$} \\
\hline & & & ELISA & [75] \\
\hline & & NASBA & Real-time & [84] \\
\hline & \multirow{4}{*}{ Vibrio parahaemolyticus } & \multirow{2}{*}{ LAMP } & Intercalating dye & {$[67,90]$} \\
\hline & & & Real-time & [91] \\
\hline & & \multirow{2}{*}{ RPA } & Real-time & [92] \\
\hline & & & LFA & {$[29,88,93]$} \\
\hline
\end{tabular}


Table 2. Cont.

\begin{tabular}{|c|c|c|c|c|}
\hline \multirow{2}{*}{ Type of Food } & \multirow{2}{*}{ Target Bacterial } & \multicolumn{2}{|c|}{ Isothermal Amplification Method } & \multirow[b]{2}{*}{ Reference } \\
\hline & & Nucleic Acid Amplification & Detection Method & \\
\hline \multirow{4}{*}{ Vegetable } & & MDA & LFA & [94] \\
\hline & Staphylococcus aureus & RPA & LFA & [88] \\
\hline & \multirow{2}{*}{ Salmonella spp. } & LAMP & Real-time & {$[70]$} \\
\hline & & RPA & Real-time & {$[74]$} \\
\hline \multirow{20}{*}{ Dairy produce } & \multirow{8}{*}{ Salmonella spp. } & \multirow{3}{*}{ LAMP } & Intercalating dye & {$[68,95]$} \\
\hline & & & LFA & {$[71]$} \\
\hline & & & Real-time & [96] \\
\hline & & \multirow[t]{2}{*}{ RPA } & LFA & [29] \\
\hline & & & CRISPR/Cas12a & [97] \\
\hline & & HDA & LFA & [37] \\
\hline & & \multirow{2}{*}{ NASBA } & ECL & [75] \\
\hline & & & Real-time & [16] \\
\hline & \multirow{3}{*}{ Escherichia coli O157:H7 } & LAMP & Intercalating dye & [95] \\
\hline & & \multirow{2}{*}{ RPA } & Real-time & [96] \\
\hline & & & LFA & {$[29,98]$} \\
\hline & \multirow{3}{*}{ Listeria monocytogenes } & \multirow{2}{*}{ RPA } & Real-time & [99] \\
\hline & & & LFA & {$[29,80-82]$} \\
\hline & & NASBA & ELISA & [83] \\
\hline & \multirow{3}{*}{ Vibrio parahaemolyticus } & LAMP & Intercalating dye & [95] \\
\hline & & \multirow{2}{*}{ RPA } & Real-time & [96] \\
\hline & & & LFA & [29] \\
\hline & \multirow{3}{*}{ Staphylococcus aureus } & LAMP & Intercalating dye & [95] \\
\hline & & HDA & Fluorescence & [86] \\
\hline & & NASBA & Real-time & [100] \\
\hline
\end{tabular}

Abbreviations used in the table: LAMP, loop-mediated isothermal amplification; RPA, recombinase polymerase amplification; HDA, helicase-dependent amplification; NASBA, nucleic acid sequence-based amplification; MDA, multiple strand displacement amplification; LFA, lateral flow assay; ECL, electrochemiluminescent; ELISA, enzyme-linked immunosorbent assay; CRISPR/Cas12a, clustered regularly interspaced short palindrome repeats/Cas12a.

Phenolic compounds contain secondary metabolites, such as polyphenols, tannic acids, caffeic acids, and chlorogenic acids, found in strawberries, citrus fruits, and potatoes $[19,101]$. These secondary metabolites can react with primary reactive residues of enzymes/proteins during amplification to change their intrinsic properties [102]. Consequently, the extraction of high-purity DNA is complex, and amplification can be inhibited $[19,26]$. Tannins are readily oxidized to bind proteins and nucleic acids irreversibly, thereby forming high molecular weight complexes, which makes DNA extraction difficult $[103,104]$. It is possible to prevent oxidation of polyphenols by adding polyvinylpyrrolidone and sodium acetate, and by adding soluble PEG to prevent the formation of free radicals, high-purity DNA can be obtained $[105,106]$. However, besides this, phenolic compounds can inhibit amplification by interfering with the activity of DNA polymerases, DNA restriction enzymes, and RNA-dependent reverse transcriptases [19,57].

High concentrations of calcium ions in milk can inhibit nucleic acid amplification through competitive binding to DNA polymerases with magnesium ions, a cofactor of DNA polymerase and helicase [104]. Milk-based amplification inhibition occurred during MDA for detecting S. Typhimurium and Cronobacter sakazakii [107]. Additionally, MDA was amplified in the presence of $14-16 \%$ milk, which was even lower than the quantity which RPA was inhibited (15-25\%), thereby confirming the weak resistance to food matrices. Additionally, Santiago-Felipe et al. [57] reported that this inhibition could be because of calcium ions in milk. 


\section{Inhibitors Originating from Isothermal Amplification Processes}

Various inhibitors repress the isothermal amplification technique for detecting bacteria, including food-borne pathogens. These inhibitors originate from amplification or detection processes and the food metrix (Table 3).

Table 3. Inhibitors from the isothermal amplification reaction process.

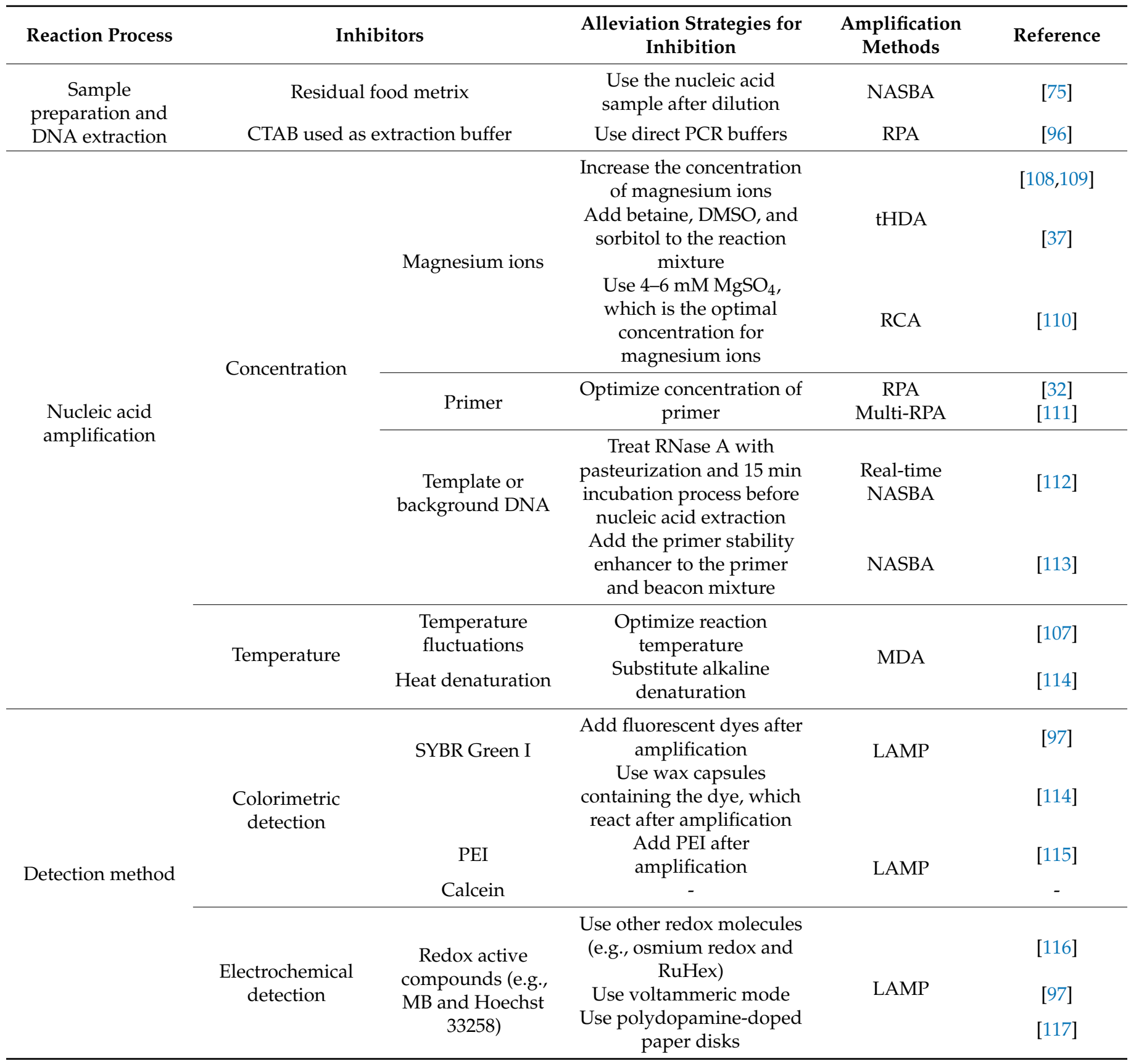

Abbreviations used in the table: NASBA, nucleic acid sequence-based amplification; CTAB, cetyltrimethyl ammonium bromide; PCR, polymerase chain reaction; RPA, recombinase polymerase amplification; DMSO, dimethyl sulfoxide; tHDA, thermophilic form of HDA; RCA, rolling circle amplification; MDA, multiple strand displacement amplification; LAMP, loop-mediated isothermal amplification; PEI, polyethyleneimine; MB, methylene blue; RuHex, ruthenium hexamine.

Bst DNA polymerase and helicase that enables isothermal amplification require a relatively high concentration of magnesium ions of about $4-8 \mathrm{mM}$ compared to Taq DNA polymerase [38]. However, magnesium ions can inhibit molecular amplification depending on the concentration in the reaction mixture [110]. Murakami et al. [110] reported that by in- 
creasing the background signal amplification in RCA, the concentration of magnesium ions inhibited the signal during target gene amplification. $\mathrm{Nb}$.BsmI, a nicking enzyme, needs magnesium ions to enhance amplification efficiency. Therefore, optimizing magnesium ion concentrations (4-6 mM MgSO 4 ) and decreasing dNTPs and DNA polymerase concentrations can decrease background signal amplifications. Doseeva et al. [109] conducted a study to alleviate magnesium ion-dependent inhibition because the concentration of magnesium ions affected the amplification efficiency of tHDA. Results indicated that as the concentration of magnesium ions and that of the dATPs improved, the signal-to-noise ratio increased 1.5-2.0 times. It was also observed that the optimal concentrations of $\mathrm{MgSO}_{4}$, dATP, and dNTP were 4, 3, and $0.4 \mathrm{mmol} / \mathrm{L}$, respectively. Additionally, betaine, DMSO, and sorbitol, which help the combined effect of magnesium ions and dATP during molecular amplification, were added to increase the efficiency and specificity of amplification in tHDA.

The inappropriate concentration of primers can inhibit molecular amplification processes. Thus, SSB proteins either inhibit the strand exchange activity of recombinase T4 UvsX or compete with recombinase proteins in RPA [118]. Additionally, primers for one target can inhibit the amplification of another target [32]. Therefore, it is essential to optimize primer concentration [32,36].

DNA/RNA templates as amplification targets can also inhibit molecular amplification. RPA reactions are more sensitive to inhibitors when the DNA concentration of the reaction mixture for amplification is close to that of the detection limit or when the background DNA concentration is high [36]. Additionally, in the initial denaturation step for denaturing the secondary structure of mRNAs before NASBA amplification, short or partially digested DNA molecules can be denatured and inhibited, thereby acting as a substrate for NASBA [118]. Simpkins et al. [84] overcame the induction of mRNA degradation using RNase enzymes in cells through pasteurization and a $15 \mathrm{~min}$ incubation before the nucleic acid extraction. The combination of RNase A, treatment, and molecular labeling based real-time NASBA assay successfully detected viable L. monocytogenes cells in meat and salmon products without an initial denaturation step that can cause inhibition. Additionally, Sidoti et al. [112] suggested that adding 60\% DMSO to NASBA primers and beacon mixtures, although not food samples, improved results through oligonucleotide stabilization maximization.

The colorimetric method, which is widely used to identify amplicons after amplification, can be inhibited using some compounds, such as intercalating dyes or cationic polymers [22]. SYBR Green I is a fluorescent dye widely used for colorimetric isothermal amplification detection because of its high detection sensitivity of amplified nucleic acids $[15,114,119]$. Therefore, it has been reported that if such a fluorescent dye was added directly to the reaction mixture before LAMP and reacted during amplification, the amplification process will be inhibited. However, if a fluorescent dye was added after amplification, the amplification result can vary owing to cross-contamination and aerosol contamination [114,120]. This inhibition was due to the strong bonding of the dye to ssDNA, and the ability to bind LAMP and loop primers in real-time to prevent primer annealing or interference with the activity of Bst DNA polymerase [121]. Hence, to prevent this inhibition, studies have allowed these fluorescent dyes to react after amplification in a closed tube system [114,122]. Wax capsules containing fluorescent dye have been reported too. They preserve the fluorescent dyes before amplification and allow the fluorescent dyes to react with amplicons when the wax melts after amplification [114]. Additionally, a study was also reported in which the fluorescent dye was applied to the inner part of the tube's cap. Then the tube was rotated after amplification to allow the fluorescent dye to react with the amplicon [121]. Similarly, nonmutagenic noncytotoxic fluorescent intercalator (EvaGreen) had less amplification inhibition capacities compared to SYBR Green I because of its characteristic of fluorescing only when bound to dsDNA. Thus, it was suggested that it could replace SYBR Green I [11,123]. 
DNA-binding dyes can also inhibit detection after nucleic acid amplification [122]. When polyethyleneimine (PEI), a cationic polymer widely used as a nucleic acid precipitating agent for nucleic acid purification, is added to the amplicon to precipitate the insoluble LAMP amplicon-PEI complex, it enables the sequence-specific visual detection of trace quantities of nucleic acids [124]. However, since the insoluble DNA-PEI complex neutralizes the negative charge of DNAs and consequently inhibits LAMP, it should be added after amplification [115]. Metal ion indicators, such as $\mathrm{MnCl}_{2}$ and calcein, can also be added to the reaction mixture before amplification, thereby enabling amplification and detection to be conducted in a closed tube system. Wastling et al. [115] compared the sensitivity of LAMP using a metal ion indicator and calcein supplemented with $\mathrm{MnCl}_{2}$. Results indicated a lower LAMP sensitivity than calcein alone.

During electrochemical monitoring developed to digitize amplicon detection, amplification inhibition is proposed to occur due to partial defects in redox active compounds [22] Methylene blue (MB) has a lower LAMP amplification efficiency than other redox molecules with binding activity $\left(10^{4}-10^{5} \mathrm{M}^{-1}\right)$ to dsDNA, a Hoechst 33258 redox molecule, which is unsuitable for real-time monitoring of LAMP, as it limits DNA amplification and detection in the solution phase, and strongly inhibits enzyme activity of polymerase for endpoint DNA detection [116]. Replacing DNA dyes can improve this LAMP inhibition. Osmium redox showed high binding activity and stability during isothermal amplification. In contrast, real-time electrochemical detection without inhibition detected ruthenium hexamine (RuHex) because it lacked an intercalating ligand and bound electrostatically to the anionic dsDNA backbone [125,126]. Ahmed et al. [127] used RuHex to successfully detect without inhibition because it can be used as an indicator to monitor LAMP amplicons instead of immobilizing the probe to the electrode's surface. Additionally, the voltammetry mode, developed based on the electrochemical reaction of free dGTP molecules in the carbon nanotube array electrode, can be used without inhibition because no secondary indicator exists. Polydopamine-doped paper disks eliminated LAMP inhibitors by reacting with milk components and calcium ions, thereby enabling the simultaneous multiplex detection of food-borne pathogens without inhibition $[43,117,120]$. Alternatively, the electrochemical monitoring of HDA uses an electroactive intercalator instead of a fluorescent probe. Here the redox probe inhibits the amplification of the specific sequence of the E. coli plasmid, so that the amplification rate of electrochemical monitoring would be slower than that of fluorescent real-time amplification [11].

\section{Conclusions}

Inhibitors originating from food matrices, DNA extraction reactions and nucleic acid amplification reactions can adversely affect isothermal amplification techniques by inhibiting amplification to detect food-borne pathogens. Nevertheless, due to the complex nature of the food matrix, food-origin inhibitors, including inhibition mechanisms for molecular analysis, have not been fully characterized yet. Additionally, studies on the inhibitory mechanisms of inhibitors obtained during isothermal amplification processes are still insufficient and have not been clearly established. The above-mentioned removal strategies for inhibiting nucleic acid amplification are rather limited and uneconomical because they only target specific inhibitors, and have not been proven to be applicable to various inhibitors. Therefore, further studies on nucleic acid amplification inhibitors and inhibitor removal strategies are needed to detect food-borne pathogens in food using isothermal amplification technologies without inhibition of nucleic acid amplification inhibitors. In the future, these studies will lead to the manufacture of a ready-to-use kit that simultaneously purifies and removes inhibitors. In this case, efficiency is guaranteed for accurate detection of food-borne pathogens in complex food matrices and for the POCT application of these isothermal amplification technologies. 


\begin{abstract}
Author Contributions: Y.-J.M.: Conceptualization; Investigation; Writing—original draft; Writingreview \& editing. S.-Y.L.: Writing-review \& editing. S.-W.O.: Funding acquisition; Project administration; Supervision; Writing-review \& editing. All authors have read and agreed to the published version of the manuscript.
\end{abstract}

Funding: This work was supported by the National Research Foundation of Korea (NRF) grant funded by the Korea government (MSIT) (2021R1A2C1014181).

Institutional Review Board Statement: Not applicable.

Informed Consent Statement: Not applicable.

Data Availability Statement: Not applicable.

Conflicts of Interest: The authors declare no conflict of interest.

\title{
References
}

1. Osaili, T.M.; Hasan, F.; Dhanasekaran, D.K.; Obaid, R.S.; Al-Nabulsi, A.A.; Ayyash, M.; Karam, L.; Savvaidis, I.N.; Holley, R. Effect of active essential oils added to chicken tawook on the behaviour of Listeria monocytogenes, Salmonella spp. and Escherichia coli O157: H7 during storage. Int. J. Food Microbiol. 2021, 337, 108947. [CrossRef] [PubMed]

2. Chai, C.; Oh, S.W. Electrochemical impedimetric biosensors for food safety. Food Sci. Biotechnol. 2020, 29, 879-887. [CrossRef] [PubMed]

3. Kim, J.H.; Oh, S.W. Rapid and sensitive detection of E. coli O157: H7 and S. Typhimurium in iceberg lettuce and cabbage using filtration, DNA concentration, and qPCR without enrichment. Food Chem. 2020, 327, 127036. [CrossRef] [PubMed]

4. Rajapaksha, P.; Elbourne, A.; Gangadoo, S.; Brown, R.; Cozzolino, D.; Chapman, J. A review of methods for the detection of pathogenic microorganisms. Analyst 2019, 144, 396-411. [CrossRef] [PubMed]

5. Wang, Y.; Qi, W.; Wang, L.; Lin, J.; Liu, Y. Magnetic Bead Chain-Based Continuous-Flow DNA Extraction for Microfluidic PCR Detection of Salmonella. Micromachines 2021, 12, 384. [CrossRef]

6. Tabatabaei, M.S.; Islam, R.; Ahmed, M. Applications of gold nanoparticles in ELISA, PCR, and immuno-PCR assays: A review. Anal. Chim. Acta 2021, 1143, 250-266. [CrossRef]

7. Liu, Z.; Sun, J.; Zhao, G.; Xiong, S.; Ma, Y.; Zheng, M. Transient stem-loop structure of nucleic acid template may interfere with polymerase chain reaction through endonuclease activity of Taq DNA polymerase. Gene 2021, 764, 145095. [CrossRef]

8. Zhang, H.; Li, H.; Zhu, H.; Pekárek, J.; Podešva, P.; Chang, H.; Neužil, P. Revealing the secrets of PCR. Sens. Actuators B 2019, 298, 126924. [CrossRef]

9. Asadi, R.; Mollasalehi, H. The mechanism and improvements to the isothermal amplification of nucleic acids, at a glance. Anal. Biochem. 2021, 631, 114260. [CrossRef]

10. Kumar, Y. Isothermal amplification-based methods for assessment of microbiological safety and authenticity of meat and meat products. Food Control 2021, 121, 107679. [CrossRef]

11. Barreda-García, S.; Miranda-Castro, R.; de-Los-Santos-Álvarez, N.; Miranda-Ordieres, A.J.; Lobo-Castañón, M.J. Helicasedependent isothermal amplification: A novel tool in the development of molecular-based analytical systems for rapid pathogen detection. Anal. Bioanal. Chem. 2018, 410, 679-693. [CrossRef] [PubMed]

12. Hu, J.; Wang, Y.; Su, H.; Ding, H.; Sun, X.; Gao, H.; Geng, Y.; Wang, Z. Rapid analysis of Escherichia coli O157: H7 using isothermal recombinase polymerase amplification combined with triple-labeled nucleotide probes. Mol. Cell Probes 2020, 50, 101501. [CrossRef]

13. Huang, M.; Yang, F.; Fu, J.; Xiao, P.; Tu, J.; Lu, Z. Reaction parameter comparison and optimization of multiple displacement amplification. Anal. Methods 2020, 12, 46-53. [CrossRef]

14. Milton, A.A.P.; Momin, K.M.; Priya, G.B.; Ghatak, S.; Gandhale, P.N.; Angappan, M.; Das, S.; Sen, A. A novel in situ methodology for visual detection of Clostridium perfringens in pork harnessing saltatory rolling circle amplification. Anaerobe 2021, 69, 102324. [CrossRef] [PubMed]

15. Vichaibun, V.; Kanchanaphum, P. Quantitative LAMP and PCR detection of Salmonella in chicken samples collected from local markets around Pathum Thani Province, Thailand. Int. J. Food Sci. 2020, 8833173. [CrossRef]

16. Zhai, L.; Liu, H.; Chen, Q.; Lu, Z.; Zhang, C.; Lv, F.; Bie, X. Development of a real-time nucleic acid sequence-based amplification assay for the rapid detection of Salmonella spp. from food. Braz. J. Microbiol. 2019, 50, 255-261. [CrossRef]

17. Srimongkol, G.; Ditmangklo, B.; Choopara, I.; Thaniyavarn, J.; Dean, D.; Kokpol, S.; Vilaivan, T.; Somboonna, N. Rapid colorimetric loop-mediated isothermal amplification for hypersensitive point-of-care Staphylococcus aureus enterotoxin A gene detection in milk and pork products. Sci. Rep. 2020, 10, 1-11.

18. Chin, N.A.; Salihah, N.T.; Shivanand, P.; Ahmed, M.U. Recent trends and developments of PCR-based methods for the detection of food-borne Salmonella bacteria and Norovirus. J. Food Sci. Technol. 2021, 57, 1-13. [CrossRef]

19. Schrader, C.; Schielke, A.; Ellerbroek, L.; Johne, R. PCR inhibitors-occurrence, properties and removal. J. Appl. Microbiol. 2012, 113, 1014-1026. [CrossRef] 
20. Kant, K.; Shahbazi, M.A.; Dave, V.P.; Ngo, T.A.; Chidambara, V.A.; Than, L.Q.; Bang, D.D.; Wolff, A. Microfluidic devices for sample preparation and rapid detection of foodborne pathogens. Biotechnol. Adv. 2018, 36, 1003-1024. [CrossRef]

21. Sidstedt, M.; Rådström, P.; Hedman, J. PCR inhibition in GPCR, dPCR and MPS-mechanisms and solutions. Anal. Bioanal. Chem. 2020, 412, 2009-2023. [CrossRef] [PubMed]

22. Zhang, X.; Lowe, S.B.; Gooding, J.J. Brief review of monitoring methods for loop-mediated isothermal amplification (LAMP). Biosens. Bioelectron. 2014, 61, 491-499. [CrossRef]

23. Becherer, L.; Borst, N.; Bakheit, M.; Frischmann, S.; Zengerle, R.; von Stetten, F.V. Loop-mediated isothermal amplification (LAMP)-review and classification of methods for sequence-specific detection. Anal. Methods 2020, 12, 717-746. [CrossRef]

24. Tao, Y.; Yun, J.; Wang, J.; Xu, P.; Li, C.; Liu, H.; Lan, Y.; Pan, J.; Du, W. High-performance detection of Mycobacterium bovis in milk using digital LAMP. Food Chem. 2020, 327, 126945. [CrossRef] [PubMed]

25. Meagher, R.J.; Priye, A.; Light, Y.K.; Huang, C.; Wang, E. Impact of primer dimers and self-amplifying hairpins on reverse transcription loop-mediated isothermal amplification detection of viral RNA. Analyst 2018, 143, 1924-1933. [CrossRef] [PubMed]

26. Fernández-Soto, P.; Mvoulouga, P.O.; Akue, J.P.; Abán, J.L.; Santiago, B.V.; Sánchez, M.C.; Muro, A. Development of a highly sensitive loop-mediated isothermal amplification (LAMP) method for the detection of Loa loa. PLoS ONE 2014, 9, e94664. [CrossRef]

27. Shahbazi, E.; Mollasalehi, H.; Minai-Tehrani, D. Development and evaluation of an improved quantitative loop-mediated isothermal amplification method for rapid detection of Morganella morganii. Talanta 2019, 191, 54-58. [CrossRef]

28. Chen, Y.; Li, H.; Yang, L.; Wang, L.; Sun, R.; Shearer, J.E.; Sun, F. Rapid Detection of Clostridium botulinum in Food Using Loop-Mediated Isothermal Amplification (LAMP). Int. J. Environ. Res. Public Health 2021, 18, 4401. [CrossRef]

29. Ahuja, A.; Somvanshi, V.S. Diagnosis of plant-parasitic nematodes using loop-mediated isothermal amplification (LAMP): A review. J. Crop. Prot. 2021, 147, 105459. [CrossRef]

30. Leonardo, S.; Toldrà, A.; Campàs, M. Biosensors based on isothermal DNA amplification for bacterial detection in food safety and environmental monitoring. Sensors 2021, 21, 602. [CrossRef]

31. Lobato, I.M.; O'Sullivan, C.K. Recombinase polymerase amplification: Basics, applications and recent advances. Trends Anal. Chem. 2018, 98, 19-35. [CrossRef] [PubMed]

32. Lillis, L.; Siverson, J.; Lee, A.; Cantera, J.; Parker, M.; Piepenburg, O.; Lehman, D.A.; Boyle, D.S. Factors influencing recombinase polymerase amplification (RPA) assay outcomes at point of care. Mol. Cell Probes 2016, 30, 74-78. [CrossRef]

33. Zhai, J.; Wang, L.; Qiao, X.; Zhao, J.; Wang, X.; He, X. Detection of Neisseria gonorrhoeae and Chlamydia trachomatis infections in pregnant women by multiplex recombinase polymerase amplification. PLoS ONE 2021, 16, e0251119. [CrossRef] [PubMed]

34. Mayboroda, O.; Gonzalez Benito, A.; Sabaté del Rio, J.; Svobodova, M.; Julich, S.; Tomaso, H.; O'Sullivan, C.K.; Katakis, I. Isothermal solid-phase amplification system for detection of Yersinia pestis. Anal. Bioanal. Chem. 2016, 408, 671-676. [CrossRef]

35. Li, J.; Macdonald, J.; von Stetten, F. Review: A comprehensive summary of a decade development of the recombinase polymerase amplification. Analyst 2018, 144, 31-67. [CrossRef] [PubMed]

36. Du, X.J.; Zhou, T.J.; Li, P.; Wang, S. A rapid Salmonella detection method involving thermophilic helicase dependent amplification and a lateral flow assay. Mol. Cell Probes 2017, 34, 37-44. [CrossRef] [PubMed]

37. Glökler, J.; Lim, T.S.; Ida, J.; Frohme, M. Isothermal amplifications-a comprehensive review on current methods. Crit Rev. Biochem. Mol. Biol. 2021, 56, 543-586. [CrossRef]

38. Kumar, A.A.; Hennek, J.W.; Smith, B.S.; Kumar, S.; Beattie, P.; Jain, S.; Rolland, J.P.; Stossel, T.P.; Chunda-Liyoka, C.; Whitesides, G.M. From the bench to the field in low-cost diagnostics: Two case studies. Angew. Chem. Int. Ed. Engl. 2015, 54, 5836-5853. [CrossRef]

39. Yang, Z.; McLendon, C.; Hutter, D.; Bradley, K.M.; Hoshika, S.; Frye, C.; Benner, S.A. Helicase dependent isothermal amplification of DNA and RNA using self-avoiding molecular recognition systems. ChemBioChem 2015, 16, 1365-1370. [CrossRef] [PubMed]

40. Thekisoe, O.M.; Bazie, R.S.; Coronel-Servian, A.M.; Sugimoto, C.; Kawazu, S.I.; Inoue, N. Stability of loop-mediated isothermal amplification (LAMP) reagents and its amplification efficiency on crude trypanosome DNA templates. J. Vet. Med. Sci. 2009, 71, 471-475. [CrossRef]

41. Xu, L.; Duan, J.; Chen, J.; Ding, S.; Cheng, W. Recent advances in rolling circle amplification-based biosensing strategies-A review. Anal. Chim. Acta 2021, 1148, 238187. [CrossRef]

42. Hønsvall, B.K.; Robertson, L.J. From research lab to standard environmental analysis tool: Will NASBA make the leap? Water Res. 2017, 109, 389-397. [CrossRef] [PubMed]

43. Brennan, D.; Coughlan, H.; Clancy, E.; Dimov, N.; Barry, T.; Kinahan, D.; Galvin, P. Development of an on-disc isothermal in vitro amplification and detection of bacterial RNA. Sens. Actuators B 2017, 239, 235-242. [CrossRef]

44. Takahashi, M.K.; Tan, X.; Dy, A.J.; Braff, D.; Akana, R.T.; Furuta, Y.; Collins, J.J. A low-cost paper-based synthetic biology platform for analyzing gut microbiota and host biomarkers. Nat. Commun. 2018, 9, 1-12. [CrossRef] [PubMed]

45. Li, J.; Macdonald, J. Advances in isothermal amplification: Novel strategies inspired by biological processes. Biosens. Bioelectron. 2015, 64, 196-211. [CrossRef] [PubMed]

46. Kellner, M.J.; Koob, J.G.; Gootenberg, J.S.; Abudayyeh, O.O.; Zhang, F. SHERLOCK: Nucleic acid detection with CRISPR nucleases. Nat. Protoc. 2019, 14, 2986-3012. [CrossRef] [PubMed]

47. Pardee, K.; Green, A.A.; Takahashi, M.K.; Braff, D.; Lambert, G.; Lee, J.W.; Ferrante, T.; Ma, D.; Donghia, D.; Fan, M.; et al. Rapid, low-cost detection of Zika virus using programmable biomolecular components. Cell 2016, 165, 1255-1266. [CrossRef] 
48. van Emmerik, C.L.; Gachulincova, I.; Lobbia, V.R.; Daniëls, M.A.; Heus, H.A.; Soufi, A.; Nelissen, F.H.T.; van Ingen, H. Ramified Rolling Circle Amplification for efficient and flexible synthesis of nucleosomal DNA sequences. bioRxiv 2019, 676528. [CrossRef]

49. Wang, Z.; Yang, Q.; Zhang, Y.; Meng, Z.; Ma, X.; Zhang, W. Saltatory rolling circle amplification (SRCA): A novel nucleic acid isothermal amplification technique applied for rapid detection of Shigella spp. in vegetable salad. Food Anal. Methods 2018, 11, 504-513. [CrossRef]

50. Spits, C.; Le Caignec, C.; De Rycke, M.; Van Haute, L.; Van Steirteghem, A.; Liebaers, I.; Sermon, K. Optimization and evaluation of single-cell whole-genome multiple displacement amplification. Hum. Mutat. 2006, 27, 496-503. [CrossRef]

51. Tian, H.C.; Benitez, J.J.; Craighead, H.G. Single cell on-chip whole genome amplification via micropillar arrays for reduced amplification bias. PLoS ONE 2018, 13, e0191520. [CrossRef]

52. Forghani, F.; Li, S.; Zhang, S.; Mann, D.A.; Deng, X.; den Bakker, H.C.; Diez-Gonzalez, F. Detection and Serotyping of Salmonella and Escherichia coli in Wheat Flour by a Quasimetagenomic Approach Assisted by Magnetic Capture, Multiple Displacement Amplification and Real-Time Sequencing. Appl. Environ. Microbiol. 2020, 86, e00097-20. [CrossRef] [PubMed]

53. Wang, W.; Ren, Y.; Lu, Y.; Xu, Y.; Crosby, S.D.; Di Bisceglie, A.M.; Fan, X. Template-dependent multiple displacement amplification for profiling human circulating RNA. Biotechniques 2017, 63, 21-27. [CrossRef] [PubMed]

54. Jamal, R.; Li, X.; Weidhaas, J. Template length, concentration and guanidine and cytosine content influence on multiple displacement amplification efficiency. J. Microbiol. Methods 2021, 181, 106146. [CrossRef] [PubMed]

55. Long, N.; Qiao, Y.; Xu, Z.; Tu, J.; Lu, Z. Recent advances and application in whole-genome multiple displacement amplification Quant. Biol. 2020, 8, 1-16. [CrossRef]

56. Smith, T.J.; O'Connor, L.; Glennon, M.; Maher, M. Molecular diagnostics in food safety: Rapid detection of food-borne pathogens Ir. J. Agric. Food Res. 2000, 39, 309-319.

57. Santiago-Felipe, S.; Tortajada-Genaro, L.A.; Morais, S.; Puchades, R.; Maquieira, Á. Isothermal DNA amplification strategies for duplex microorganism detection. Food Chem. 2015, 174, 509-515. [CrossRef]

58. Kong, M.; Chen, X.G.; Xing, K.; Park, H.J. Antimicrobial properties of chitosan and mode of action: A state of the art review. Int. J. Food Microbiol. 2010, 144, 51-63. [CrossRef]

59. Narushima, J.; Kimata, S.; Soga, K.; Sugano, Y.; Kishine, M.; Takabatake, R.; Mano, J.; Kitta, K.; Kanamaru, S.; Shirakawa, N.; et al Rapid DNA template preparation directly from a rice sample without purification for loop-mediated isothermal amplification (LAMP) of rice genes. Biosci. Biotechnol. Biochem. 2020, 84, 670-677. [CrossRef]

60. Kalendar, R.; Boronnikova, S.; Seppänen, M. Isolation and purification of DNA from complicated biological samples. Methods Mol. Biol. 2021, 2222, 57-67.

61. Ramírez, M.H.; Salazar Duque, H.J.; Urrea Trujillo, A.I. Quality of cocoa (Theobroma cacao L.) DNA from foliar tissue at different stages of development. Acta Agron. 2018, 67, 311-318. [CrossRef]

62. Demeke, T.; Ratnayaka, I.; Phan, A. Effects of DNA extraction and purification methods on real-time quantitative PCR analysis of Roundup Ready soybean. J. AOAC Int. 2009, 92, 1136-1144. [CrossRef] [PubMed]

63. Demeke, T.; Malabanan, J.; Holigroski, M.; Eng, M. Effect of source of DNA on the quantitative analysis of genetically engineered traits using digital PCR and real-time PCR. J. AOAC Int. 2017, 100, 492-498. [CrossRef] [PubMed]

64. $\mathrm{Xu}, \mathrm{W}$. Adaptable methods to extract nucleic acid targets and evaluate quality. In Functional Nucleic Acids Detection in Food Safety Springer: Singapore, 2016; pp. 17-36.

65. Suther, C.; Moore, M.D. Quantification and discovery of PCR inhibitors found in food matrices commonly associated with foodborne viruses. Food Sci. Hum. Wellness 2019, 8, 351-355. [CrossRef]

66. Pang, B.; Yao, S.; Xu, K.; Wang, J.; Song, X.; Mu, Y.; Zhao, C.; Li, J. A novel visual-mixed-dye for LAMP and its application in the detection of foodborne pathogens. Anal. Biochem. 2019, 574, 1-6. [CrossRef]

67. Jin, Z.; Ding, G.; Li, G.; Yang, G.; Han, Y.; Hao, N.; Deng, J.; Zhang, Y.; Zhang, W.; Li, W. Rapid detection of foodborne bacterial pathogens using visual high-throughput microfluidic chip. J. Chem. Technol. Biotechnol. 2020, 95, 1460-1466. [CrossRef]

68. Arunrut, N.; Kiatpathomchai, W.; Ananchaipattana, C. Development and evaluation of real-time loop mediated isothermal amplification assay for rapid and sensitive detection of Salmonella spp. in chicken meat products. J. Food Saf. 2018, 38 , e12564. [CrossRef]

69. Fang, J.; Wu, Y.; Qu, D.; Ma, B.; Yu, X.; Zhang, M.; Han, J. Propidium monoazide real-time loop-mediated isothermal amplification for specific visualization of viable Salmonella in food. Lett. Appl. Microbiol. 2018, 67, 79-88. [CrossRef]

70. Mei, X.; Zhai, X.; Lei, C.; Ye, X.; Kang, Z.; Wu, X.; Xiang, R.; Wang, Y.; Wang, H. Development and application of a visual loopmediated isothermal amplification combined with lateral flow dipstick (LAMP-LFD) method for rapid detection of Salmonella strains in food samples. Food Control 2019, 104, 9-19. [CrossRef]

71. Kim, J.Y.; Lee, J.L. Rapid detection of Salmonella enterica serovar enteritidis from eggs and chicken meat by real-time recombinase polymerase amplification in comparison with the two-step real-time PCR. J. Food Saf. 2016, 36, 402-411. [CrossRef]

72. Chen, J.; Liu, X.; Chen, J.; Guo, Z.; Wang, Y.; Chen, G.; Chen, X.; Yan, Q.; Yang, P.; Li, R.; et al. Development of a rapid test method for Salmonella enterica detection-based on fluorescence probe-based recombinase polymerase amplification. Food Anal. Methods 2019, 12, 1791-1798. [CrossRef]

73. Zhao, L.; Wang, J.; Sun, X.X.; Wang, J.; Chen, Z.; Xu, X.; Dong, M.; Guo, Y.N.; Wang, Y.; Chen, P.; et al. Development and evaluation of the rapid and sensitive RPA assays for specific detection of Salmonella spp. in food samples. Front. Cell Infect. Microbiol. 2021, 11, 631921. [CrossRef] 
74. D'souza, D.H.; Jaykus, L.A. Nucleic acid sequence-based amplification for the rapid and sensitive detection of Salmonella enterica from foods. J. Appl. Microbiol. 2003, 95, 1343-1350. [CrossRef]

75. Lv, X.; Wang, L.; Zhang, J.; Zeng, H.; Chen, X.; Shi, L.; Cui, H.; He, X.; Zhao, L. Rapid and sensitive detection of VBNC Escherichia coli O157: H7 in beef by PMAxx and real-time LAMP. Food Control 2020, 115, 107292. [CrossRef]

76. Kim, J.H.; Oh, S.W. Development of a filtration-based LAMP-LFA method as sensitive and rapid detection of E. coli O157: H7. J. Food Sci. Technol. 2019, 56, 2576-2583. [CrossRef] [PubMed]

77. Azinheiro, S.; Carvalho, J.; Prado, M.; Garrido-Maestu, A. Correction: Azinheiro et al. Multiplex Detection of Salmonella spp., E. coli $\mathrm{O} 157$ and L. monocytogenes by qPCR Melt Curve Analysis in Spiked Infant Formula. Microorganisms 2020, 8, 1359. [CrossRef] [PubMed]

78. Wachiralurpan, S.; Sriyapai, T.; Areekit, S.; Sriyapai, P.; Augkarawaritsawong, S.; Santiwatanakul, S.; Chansiri, K. Rapid colorimetric assay for detection of Listeria monocytogenes in food samples using LAMP formation of DNA concatemers and gold nanoparticle-DNA probe complex. Front. Chem. 2018, 6, 90. [CrossRef]

79. Gao, W.; Huang, H.; Zhang, Y.; Zhu, P.; Yan, X.; Fan, J.; Chen, X. Recombinase polymerase amplification-based assay for rapid detection of Listeria monocytogenes in food samples. Food Anal. Methods 2017, 10, 1972-1981. [CrossRef]

80. Du, X.J.; Zang, Y.X.; Liu, H.B.; Li, P.; Wang, S. Recombinase polymerase amplification combined with lateral flow strip for Listeria monocytogenes detection in food. J. Food Sci. 2018, 83, 1041-1047. [CrossRef] [PubMed]

81. Wang, L.; Zhao, P.; Si, X.; Li, J.; Dai, X.; Zhang, K.; Gao, S.; Dong, J. Rapid and specific detection of Listeria monocytogenes with an isothermal amplification and lateral flow strip combined method that eliminates false-positive signals from primer-dimers. Front. Microbiol. 2020, 10, 2959. [CrossRef] [PubMed]

82. Uyttendaele, M.; Schukkink, R.; Van Gemen, B.; Debevere, J. Development of NASBA ${ }^{\circledR}$, a nucleic acid amplification system, for identification of Listeria monocytogenes and comparison to ELISA and a modified FDA method. Int. J. Food Microbiol. 1995, 27, 77-89. [CrossRef]

83. Prompamorn, P.; Sithigorngul, P.; Rukpratanporn, S.; Longyant, S.; Sridulyakul, P.; Chaivisuthangkura, P. The development of loop-mediated isothermal amplification combined with lateral flow dipstick for detection of Vibrio parahaemolyticus. Appl. Microbiol. 2011, 52, 344-351. [CrossRef] [PubMed]

84. Simpkins, S.A.; Chan, A.B.; Hays, J.; Pöpping, B.; Cook, N. An RNA transcription-based amplification technique (NASBA) for the detection of viable Salmonella enterica. Lett. Appl. Microbiol. 2000, 30, 75-79. [CrossRef] [PubMed]

85. Chen, X.; Wu, X.; Gan, M.; Xu, F.; He, L.; Yang, D.; Xu, H.; Shah, N.P.; Wei, H. Rapid detection of Staphylococcus aureus in dairy and meat foods by combination of capture with silica-coated magnetic nanoparticles and thermophilic helicase-dependent isothermal amplification. J. Dairy Sci. 2015, 98, 1563-1570. [CrossRef] [PubMed]

86. Gao, W.; Huang, H.; Zhu, P.; Yan, X.; Fan, J.; Jiang, J.; Xu, J. Recombinase polymerase amplification combined with lateral flow dipstick for equipment-free detection of Salmonella in shellfish. Bioprocess Biosyst. Eng. 2018, 41, 603-611. [CrossRef]

87. Ma, B.; Li, J.; Chen, K.; Yu, X.; Sun, C.; Zhang, M. Multiplex recombinase polymerase amplification assay for the simultaneous detection of three foodborne pathogens in seafood. Foods 2020, 9, 278. [CrossRef]

88. Garrido-Maestu, A.; Azinheiro, S.; Carvalho, J.; Prado, M. Combination of immunomagnetic separation and real-time recombinase polymerase amplification (IMS-qRPA) for specific detection of Listeria monocytogenes in smoked salmon samples. J. Food Sci. 2019, 84, 1881-1887. [CrossRef]

89. Jiang, W.; Ren, Y.; Han, X.; Xue, J.; Shan, T.; Chen, Z.; Liu, Y.; Wang, Q. Recombinase polymerase amplification-lateral flow (RPA-LF) assay combined with immunomagnetic separation for rapid visual detection of Vibrio parahaemolyticus in raw oysters Anal. Bioanal. Chem. 2020, 412, 2903-2914. [CrossRef]

90. Cao, X.; Zhao, L.; Zhang, J.; Chen, X.; Shi, L.; Fang, X.; Xie, H.; Chang, Y.; Wang, L. Detection of viable but nonculturable Vibrio parahaemolyticus in shrimp samples using improved real-time PCR and real-time LAMP methods. Food Control 2019, 103, 145-152. [CrossRef]

91. Zhu, P.; Gao, W.; Huang, H.; Jiang, J.; Chen, X.; Fan, J.; Yan, X. Rapid detection of Vibrio parahaemolyticus in shellfish by real-time recombinase polymerase amplification. Food Anal. Methods 2018, 11, 2076-2084. [CrossRef]

92. Zhang, M.; Liu, J.; Shen, Z.; Liu, Y.; Song, Y.; Liang, Y.; Li, Z.; Nie, L.; Fang, Y.; Zhao, Y. A newly developed paper embedded microchip based on LAMP for rapid multiple detections of foodborne pathogens. BMC Microbiol. 2021, 21, 197. [CrossRef]

93. Wang, Y.; Li, H.; Li, D.; Li, K.; Wang, Y.; Xu, J.; Ye, C. Multiple cross displacement amplification combined with gold nanoparticlebased lateral flow biosensor for detection of Vibrio parahaemolyticus. Front. Microbiol. 2016, 7, 2047. [CrossRef] [PubMed]

94. Anupama, K.P.; Nayak, A.; Karunasagar, I.; Maiti, B. Rapid visual detection of Vibrio parahaemolyticus in seafood samples by loop-mediated isothermal amplification with hydroxynaphthol blue dye. World J. Microbiol. Biotechnol. 2020, 36, 76. [CrossRef] [PubMed]

95. Choi, G.; Jung, J.H.; Park, B.H.; Oh, S.J.; Seo, J.H.; Choi, J.S.; Seo, T.S. A centrifugal direct recombinase polymerase amplification (direct-RPA) microdevice for multiplex and real-time identification of food poisoning bacteria. Lab Chip 2016, 16, 2309-2316. [CrossRef] [PubMed]

96. Cai, Q.; Wang, R.; Qiao, Z.; Yang, W. Single-digit Salmonella detection with the naked eye using bio-barcode immunoassay coupled with recombinase polymerase amplification and a CRISPR-Cas12a system. Analyst 2021, 146, 5271-5279. [CrossRef] 
97. Rani, A.; Ravindran, V.B.; Surapaneni, A.; Shahsavari, E.; Haleyur, N.; Mantri, N.; Ball, A.S. Evaluation and comparison of recombinase polymerase amplification coupled with lateral-flow bioassay for Escherichia coli O157: H7 detection using different genes. Sci. Rep. 2021, 11, 1881. [CrossRef] [PubMed]

98. Garrido-Maestu, A.; Azinheiro, S.; Fuciños, P.; Carvalho, J.; Prado, M. Comparative study of multiplex real-time recombinase polymerase amplification and ISO 11290-1 methods for the detection of Listeria monocytogenes in dairy products. Food Microbiol. 2020, 92, 103570. [CrossRef]

99. O'Grady, J.; Lacey, K.; Glynn, B.; Smith, T.J.; Barry, T.; Maher, M. tmRNA-A novel high-copy-number RNA diagnostic target-its application for Staphylococcus aureus detection using real-time NASBA. FEMS Microbiol. Lett. 2009, 301, 218-223. [CrossRef]

100. Clancy, E.; Higgins, O.; Forrest, M.S.; Boo, T.W.; Cormican, M.; Barry, T.; Piepenburg, O.; Smith, T.J. Development of a rapid recombinase polymerase amplification assay for the detection of Streptococcus pneumoniae in whole blood. BMC Infect. Dis. 2015, 15, 481. [CrossRef] [PubMed]

101. Raghavendra, M.P.; Kumar, P.R.; Prakash, V. Mechanism of inhibition of rice bran lipase by polyphenols: A case study with chlorogenic acid and caffeic acid. J. Food Sci. 2007, 72, E412-E419. [CrossRef]

102. Japelaghi, R.H.; Haddad, R.; Garoosi, G.A. Rapid and efficient isolation of high-quality nucleic acids from plant tissues rich in polyphenols and polysaccharides. Mol. Biotechnol. 2011, 49, 129-137. [CrossRef] [PubMed]

103. Opel, K.L.; Chung, D.; McCord, B.R. A study of PCR inhibition mechanisms using real time PCR. J. Forensic. Sci. 2010, 55, 25-33. [CrossRef] [PubMed]

104. Krause, D.O.; Smith, W.J.; Mcsweeney, C.S. Extraction of microbial DNA from rumen contents containing plant tannins. Biotechniques 2001, 31, 294-298. [PubMed]

105. Sharma, P.; Purohit, S.D. An improved method of DNA isolation from polysaccharide rich leaves of Boswellia serrata Roxb. Indian J. Biotechnol. 2012, 11, 67-71.

106. Moser, C.; Gatto, P.; Moser, M.; Pindo, M.; Velasco, R. Isolation of functional RNA from small amounts of different grape and apple tissues. Mol. Biotechnol. 2004, 26, 95-100. [CrossRef]

107. Barreda-García, S.; Miranda-Castro, R.; de-Los-Santos-Álvarez, N.; Miranda-Ordieres, A.J.; Lobo-Castañón, M.J. Comparison of isothermal helicase-dependent amplification and PCR for the detection of Mycobacterium tuberculosis by an electrochemical genomagnetic assay. Anal. Bioanal. Chem. 2016, 408, 8603-8610. [CrossRef]

108. Munawar, M.A.; Martin, F.; Toljamo, A.; Kokko, H.; Oksanen, E. RPA-PCR couple: An approach to expedite plant diagnostics and overcome PCR inhibitors. BioTechniques 2020, 69, 270-280. [CrossRef]

109. Doseeva, V.; Forbes, T.; Wolff, J.; Khripin, Y.; O’Neil, D.; Rothmann, T.; Nazarenko, I. Multiplex isothermal helicase-dependent amplification assay for detection of Chlamydia trachomatis and Neisseria gonorrhoeae. Diagn. Microbiol. Infect. Dis 2011, 71, 354-365. [CrossRef]

110. Murakami, T.; Sumaoka, J.; Komiyama, M. Sensitive isothermal detection of nucleic-acid sequence by primer generation-rolling circle amplification. Nucleic Acids Res. 2009, 37, e19. [CrossRef] [PubMed]

111. Paez, J.G.; Lin, M.; Beroukhim, R.; Lee, J.C.; Zhao, X.; Richter, D.J.; Gabriel, S.; Herman, P.; Sasaki, H.; Altshuler, D.; et al. Genome coverage and sequence fidelity of $\$ 29$ polymerase-based multiple strand displacement whole genome amplification. Nucleic Acids Res. 2004, 32, e71. [CrossRef]

112. Sidoti, F.; Bergallo, M.; Terlizzi, M.E.; Piasentin Alessio, E.P.; Astegiano, S.; Gasparini, G.; Cavallo, R. Development of a quantitative real-time nucleic acid sequence-based amplification assay with an internal control using molecular beacon probes for selective and sensitive detection of human rhinovirus serotypes. Mol. Biotechnol. 2012, 50, 221-228. [CrossRef] [PubMed]

113. Feng, J.; Dai, Z.; Tian, X.; Jiang, X. Detection of Listeria monocytogenes based on combined aptamers magnetic capture and loop-mediated isothermal amplification. Food Control 2018, 85, 443-452. [CrossRef]

114. Zhang, X.; Qu, K.; Li, Q.; Cui, Z.; Zhao, J.; Sun, X. Recording the reaction process of loop-mediated isothermal amplification (LAMP) by monitoring the voltammetric response of 2'-deoxyguanosine 5'-triphosphate. Electroanalysis 2011, 23, 2438-2445. [CrossRef]

115. Wastling, S.L.; Picozzi, K.; Kakembo, A.S.; Welburn, S.C. LAMP for human African trypanosomiasis: A comparative study of detection formats. PLoS Negl. Trop. Dis. 2010, 4, e865. [CrossRef] [PubMed]

116. Deféver, T.; Druet, M.; Evrard, D.; Marchal, D.; Limoges, B. Real-time electrochemical PCR with a DNA intercalating redox probe. Anal. Chem. 2011, 83, 1815-1821. [CrossRef] [PubMed]

117. Sun, Y.; Quyen, T.L.; Hung, T.Q.; Chin, W.H.; Wolff, A.; Bang, D.D. A lab-on-a-chip system with integrated sample preparation and loop-mediated isothermal amplification for rapid and quantitative detection of Salmonella spp. in food samples. Lab Chip 2015, 15, 1898-1904. [CrossRef] [PubMed]

118. Nadal, A.; Coll, A.; Cook, N.; Pla, M. A molecular beacon-based real time NASBA assay for detection of Listeria monocytogenes in food products: Role of target mRNA secondary structure on NASBA design. J. Microbiol. Methods 2007, 68, 623-632. [CrossRef]

119. Tao, Z.Y.; Zhou, H.Y.; Xia, H.; Xu, S.; Zhu, H.W.; Culleton, R.L.; Han, E.T.; Lu, F.; Fang, Q.; Gu, Y.P.; et al. Adaptation of a visualized loop-mediated isothermal amplification technique for field detection of Plasmodium vivax infection. Parasit Vectors 2011, 4, 115. [CrossRef]

120. Quyen, T.L.; Ngo, T.A.; Bang, D.D.; Madsen, M.; Wolff, A. Classification of multiple DNA dyes based on inhibition effects on real-time loop-mediated isothermal amplification (LAMP): Prospect for point of care setting. Front. Microbiol. 2019, 10, 2234. [CrossRef] 
121. Dixit, K.K.; Verma, S.; Singh, O.P.; Singh, D.; Singh, A.P.; Gupta, R.; Negi, N.S.; Das, P.; Sundar, S.; Singh, R.; et al. Validation of SYBR Green I-based closed tube loop mediated isothermal amplification (LAMP) assay and simplified direct-blood-lysis (DBL)-LAMP assay for diagnosis of visceral leishmaniasis (VL). PLoS Negl. Trop. Dis. 2018, 12, e0006922. [CrossRef]

122. Ramalingam, N.; Liu, H.B.; Dai, C.C.; Jiang, Y.; Wang, H.; Wang, Q.M.; Hui, K.M.; Gong, H.Q. Real-time PCR array chip with capillary-driven sample loading and reactor sealing for point-of-care applications. Biomed. Microdevices 2009, 11, 1007-1020. [CrossRef] [PubMed]

123. Hongwarittorrn, I.; Chaichanawongsaroj, N.; Laiwattanapaisal, W. Semi-quantitative visual detection of loop mediated isothermal amplification (LAMP)-generated DNA by distance-based measurement on a paper device. Talanta 2017, 175, 135-142. [CrossRef] [PubMed]

124. Mori, Y.; Hirano, T.; Notomi, T. Sequence specific visual detection of LAMP reactions by addition of cationic polymers. BMC Biotechnol. 2006, 6, 3. [CrossRef]

125. Steel, A.B.; Herne, T.M.; Tarlov, M.J. Electrostatic interactions of redox cations with surface-immobilized and solution DNA Bioconjug. Chem. 1999, 10, 419-423. [CrossRef]

126. Vidic, J.; Vizzini, P.; Manzano, M.; Kavanaugh, D.; Ramarao, N.; Zivkovic, M.; Radonic, V.; Knezevic, N.; Giouroudi, I.; Gadjanski, I. Point-of-need DNA testing for detection of foodborne pathogenic bacteria. Sensors 2019, 19, 1100. [CrossRef] [PubMed]

127. Ahmed, M.U.; Nahar, S.; Safavieh, M.; Zourob, M. Real-time electrochemical detection of pathogen DNA using electrostatic interaction of a redox probe. Analyst 2013, 138, 907-915. [CrossRef] [PubMed] 